\title{
INFLUENCE OF ADMINISTERING WATERMELON RIND WATER EXTRACTS (Citrullus vulgaris Schard) ON GLUCOSE LEVEL OF MALE WHITE RATS (Rattus norvegicus) INDUCED WITH STREPTOZOTOSIN
}

\author{
Hasyim As'ari ${ }^{1}$, Sugiyanta ${ }^{2}$ \\ ${ }^{1}$ Health Ministry Polytechnic, Surabaya, ${ }^{2}$ Faculty of Medicine, Jember State University, Jember, Indonesia
}

\begin{abstract}
Watermelon rind water extract contain of citrulline. Citrulline is a precursor of generating Nitric Oxide (NO). NO possibly reduced the level of blood glucose in streptozotosin-induced diabetic rats. This study was a laboratory experimental study completely randomized design. A number of 30 male albino Wistar rats weighting $100-200 \mathrm{gr}$ were devided into six groups $(N=5)$, with group 1 served as normal control group. The other groups were given streptozotosin to induced diabetes mellitus. The rats in control diabetic group were given CMC 0,5\%, the others were given watermelon rind extracs for 8 days with different doses for each group. The results showed that serum glucose levels in posttest control group was significantly different, from that group of the watermelon rind extract $250 \mathrm{mg} / \mathrm{kg} b w /$ day $(p=0.000)$, groups of watermelon rind extract 500 $\mathrm{mg} / \mathrm{kgbw} /$ day $(\mathrm{p}=0.000)$ and groups of watermelon rind extract $1000 \mathrm{mg} / \mathrm{kg} \mathrm{bw/day}(p=0.000)$. The level of triglyceride in

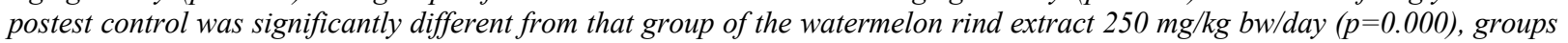
of watermelon rind extract $500 \mathrm{mg} / \mathrm{kgbw} / \mathrm{day}(\mathrm{p}=0.000)$ and groups of watermelon rind extract $1000 \mathrm{mg} / \mathrm{kgbw} / \mathrm{day}(p=0.000)$. The conclusion, the watermelon rind water extrac can be used to reduced glucose serum level (250, 500, $1000 \mathrm{mg} / \mathrm{kg}$ bw) with the optimal dose was $500 \mathrm{mg} / \mathrm{kg}$ bw/day with the optimal dose was $1000 \mathrm{mg} / \mathrm{kg} \mathrm{bw/day}$.
\end{abstract}

Keywords: Watermelon rind; streptozotosin; diabetes mellitus; glucose

\section{ABSTRAK}

Ekstrak air kulit buah semangka mengandung citrulline. Citrulline adalah prekursor untuk menghasilkan Nitric Oxide (NO). NO kemungkinan menurunkan tingkat glukosa darah pada tikus diabetes yang diinduksi streptozotosin. Penelitian ini merupakan penelitian eksperimental laboratorium dengan rancangan acak lengkap. Sebanyak 30 ekor tikus Wistar albino jantan dengan bobot 100-200 gr dibagi menjadi enam kelompok $(N=5)$, dengan kelompok 1 sebagai kelompok kontrol normal. Kelompok lain diberi streptozotosin untuk menginduksi diabetes mellitus. Tikus kelompok diabetes kontrol diberi CMC 0,5\%, tikus lainnya diberi ekstrak kulit buah semangka selama 8 hari dengan dosis yang berbeda untuk tiap kelompok. Hasil penelitian menunjukkan bahwa kadar glukosa serum pada kelompok kontrol posttest berbeda nyata, yaitu kelompok ekstrak kulit buah semangka $250 \mathrm{mg} / \mathrm{kg}$ bb/hari ( kelompok ekstrak kulit buah semangka $1000 \mathrm{mg} / \mathrm{kgbw} / \mathrm{hari}(\mathrm{p}=0,000)$. Kadar trigliserida pada postest control berbeda nyata dengan kelompok ekstrak kulit buah semangka $250 \mathrm{mg} / \mathrm{kg}$ bb/hari $(p=0,000)$, kelompok ekstrak kulit buah semangka 500 $\mathrm{mg} / \mathrm{kgbb} / \mathrm{hari}(\mathrm{p}=0,000)$ dan kelompok ekstrak kulit buah semangka ekstrak kulit buah semangka $1000 \mathrm{mg} / \mathrm{kgbb} / \mathrm{hari}$ $(p=0,000)$. Kesimpulan ekstrak air kulit buah semangka dapat digunakan untuk menurunkan kadar glukosa serum (250, 500, $1000 \mathrm{mg} / \mathrm{kg} \mathrm{bb)} \mathrm{dengan} \mathrm{dosis} \mathrm{optimal} 500 \mathrm{mg} / \mathrm{kg}$ bb/hari dengan dosis optimal $1000 \mathrm{mg} / \mathrm{kg}$ bb/hari.

Kata kunci: Kulit buah semangka; streptozotosin; diabetes mellitus; glukosa

Correspondence: Hasyim Asy’ari, Health Ministry Polytechnic, Jalan Pucang Jajar Tengah 56, Surabaya, Indonesia. E-mail: d.mutmainnah@gmail.com

pISSN:2355-8393 • eISSN: 2599-056x • doi:

- Fol Med Indones. 2020;56:174-177 • Received 12 Sept 2018 • Accepted 11 Apr 2019

- Open access under CC-BY-NC-SA license • Available at https://e-journal.unair.ac.id/FMI/

\section{INTRODUCTION}

On 2025, Diabetes Milletus is predictically reached 350 million that is a metabolic disorder of blood glucose which isn't commonly used, it caused hyperglycemia (Dods 1996, Sacks 2001). It caused a complication, microvascular (retinopati, nefropati, neuropati) macrovascular (heart ischemia, stroke, atherosclerosis) and both complictaion (Payne 2002). Hyperglycemia in especially Type 2 DM (Non Insulin Dependent Diabetes Mellitus (NIDDM) that was $95 \%-98 \%$ of diabetics was caused of the ability decrease of insulin in pheriperal 
tissue (insulin resistance) and bheta cells disfunction that caused the disability of pancreas to produce a sufficient insulin that replaced insulin resistance which was consequently followed by insulin deficiency (Sacks, 2001).

Insulin decreased blood glucose level by increasing glucose uptake of muscles and adiposa tissue, increased glucose oxidation and glycogen synthesis. Insulin also inhibited adipose tissue liposysis, glycogenolysis and gluconeogenesis in the liver and increased lipogenesis (Jakus, 2000).

Lipogenesis enhancement occured due to excessive release of adipose tissue (lipolysis) and uptake reduction of skeletal muscle so that more free fatty acid entered the liver. The liver response would increase the synthesis of triglycerides, VLDL and cholesterol ester synthesis (Murray et al., 2003) which are subsequently secreted into the circulation. DM management covered : dietary habit management, regular physical exercise and the use of pharmacological therapy, by optimizing the use of herbal ingredients (Subroto, 2006) that was a watermelon rind (Citrullus vulgaris Schard) which contained active compound of citrulline $24,4 \mathrm{mg} / \mathrm{g}$ dry weight (Rimando \& Perkins-Veazie 2005). Citrulline played a role as formation precursors of NO, which $\mathrm{NO}$ directly involved in an insulin secretion regulation with causing membrane depoarization and increasing the concentra-tion of $\mathrm{Ca} 2+$ intracellular. $\mathrm{NO}$ in the cell would caused a retension of $\mathrm{K}+$ intracellular which generated membrane depolarization. Subsequently it opened $\mathrm{Ca} 2+$ channel, so that $\mathrm{Ca} 2+$ influx increased and then an insulin secretion. Furthermore, it stimulated glyco-genesis in hepar. As a result, it decreased blood glucose level (Laffranchi, 2002) by increasing the bond of insulin and insulin receptor. Therefore it caused translocation of GLUT 4 on the surface of membrane cell that optimally generated a carriage of glucose. (Murray et al., 2003). In order to prove Anti-diabetic effect of woternelon rind, it would conduct an experimental research by using diabetic mice which given a streptozotocin injection with a single dosage of $50 \mathrm{mg} / \mathrm{kgBW}$.

\section{MATERIALS AND METHODS}

Laboratory experimental research method used Completely Randomized Design. A research sample used a healthy male white rats (Rattus novergicus) averaging $1-2$ months old with $100-200$ gram weight. The sample used 30 streptozotocin-induced mice (STZ,2-deoksi-2-(3-(methyl-3-nitrosoureido)-Dglucopyranosa) from MP Biomedicals, LLC with catalog number of 100557 , then made as DM2. The independent variable is giving watermelon rind water extract of red seedless watermelon. The dependent variable is glucose serum level measured by enzimatic method (GOD - PAP) in $\mathrm{mg} / \mathrm{dl}$. The dosage of giving Watermelon rind water extract is a control group without watermelon extract which only given water, the treatment group with a dosage of $250 \mathrm{mg} / \mathrm{kgbw} /$ day, $500 \mathrm{mg} / \mathrm{kgbw} /$ day and $1000 \mathrm{mg} / \mathrm{kgbw} /$ day.

The analitical data perfomed to know the differences of lowering blood glucose level which given watermelon rind extract between groups is one-way analysis of variance (ANOVA) (with assumption of homogenous data and normal distribution) with a margin of error $5 \%$. If there is a meaningfull difference, Least Significant Difference (LSD) is used due to know the difference between treatments.

\section{RESULTS}

LSD test was performed to observe the blood glucose level difference between groups. The diffenrence described that there were meaningful differences $(p<0.05)$ for the glucose level between positive control groups and watermelon rind extract groups with dosage $250 \mathrm{mg} / \mathrm{kg}$ bw/day $(\mathrm{p}=0.000), 500 \mathrm{mg} / \mathrm{kg}$ bw/day $(\mathrm{p}=0.000)$ and $1000 \mathrm{mg} / \mathrm{kg}$ bw $(\mathrm{p}=0.000)$.

Table 2 shows that there are meaningful differences between the extract groups of $250 \mathrm{mg} / \mathrm{kg}$ bw and the extract groups of $500 \mathrm{mg} / \mathrm{kg}$ bw $(\mathrm{p}=0.002)$ and also the extract groups of $1000 \mathrm{mg} / \mathrm{kg}$ bw $(\mathrm{p}=0.003)$. It also shown that there ae meaningful differences between groups. The extract group of $500 \mathrm{mg} / \mathrm{kg} \mathrm{bw}$ is not meaningfully different from the extract group of 1000 $\mathrm{mg} / \mathrm{kg}$ bw $(\mathrm{p}=0.872)$.

\section{DISCUSSION}

\section{The influence of streptozotocin injection}

In this research, the injection of STZ $50 \mathrm{mg} / \mathrm{kg}$ bb to an experimental animal with intraperitoneal single dosage, in all groups which were exsperienced DM, the blood glucose level was increased to over $250 \mathrm{mg} / \mathrm{dl}$. It was meaningfully higher than the groups was not injected STZ and followed by the enhancement of triglyceride level. It was based on the research conducted by Cattopadhyay and Bandyopadhyay, (2005) and Joeliantina, (2008) on a reasearch which used material of herbs as anti-diabetic. The dosage of STZ used to induce DM was a single dosage of $50 \mathrm{mg} / \mathrm{kg}$ bb and to show the result of hyperglycemia on the third day and the seventh day. By using this dosage, it assumed that 
there was DM type 2, because the diabetic control groups could stay live untill the third day and the seventh day. By this dosage, it was suspected DM Type 2 , because diabetic control groups could stay live until the fintenth day and the sulfonylurea treted groups could respond well, although without administering insulin (Cattopadhyay \& Bandyopadhyay, 2005). Administering STZ caused the canges of DNA pancreatic $\beta$ cell that there was a DNA fragmentation through DNA alkylation (Szkudelski, 2001). STZ also produced ROS that cuased DNA fragmentation and cell demage. The formation of superoxide anions results from STZ action in mitochondria and an enhancement the activity of xantin oksidase. It shown that it was obstacles of STZ on the Kreb Cycles. Therefore, it decreased the concumption of mitocondria oxygen. This effect strongly limited the production of ATP Mitocondra and reduced nucleotida in pancreatic $\beta$ cell (Szkudelski, 2001).

The synergistic action of NO and ROS also played a role in an occurance of DNA fragmentation. NO and ROS could form peroxinitrite that could cause DNA damages. DNA damages after administering STZ would activate poly ADP ribosylation. This process decreased
NAD cellular and ATP. Moreover it inhibited insulin synthesis and secretion (Szkudelski, 2001). Therefore, STZ was laso NO donor as well as watermelon rind. However, NO that resulted from STZ was followed by the formation of high ROS which caused the demage of DNA pancreatic $\beta$ cell. NO from watermelon rind played a role as a mediator that functions to increase insulin secretion and GLUT 4 translocation to the plasma membrane.

\section{The role of watermelon skin extract in reducing serum glucose levels}

The result of variance analysis test between groups on the serum glucose level showed a meaningful difference result $\mathrm{p}=0,000$. LSD Test also showed that the positive control groups were meaningfully difference to watermelon rind extract groups with dosage $250 \mathrm{mg} / \mathrm{kg}$ bw/day, $500 \mathrm{mg} / \mathrm{kg}$ bw/day and $1000 \mathrm{mg} / \mathrm{kg}$ bw/day and the dosage was also meaningfully difference. The result of test showed that administering watermelon rind extract influenced the degression of serum glucose level. It was because watermelon rind contains citrulline.

Table 1. Difference of blood glucose level with $\mathrm{p}<0.05$ between positive control groups

\begin{tabular}{ccc}
\hline Dependent Variable & $\mathrm{F}_{\text {count }}$ & Sig. \\
\hline Glucose Level & 47.474 & $0.000^{*}$ \\
\hline
\end{tabular}

Table 2. Differences between the extract groups

\begin{tabular}{|c|c|c|c|c|c|}
\hline $\begin{array}{l}\text { Dependent } \\
\text { Variable }\end{array}$ & (1) Group & (J) Group & $\begin{array}{l}\text { Average } \\
\text { Difference } \\
\quad(\mathrm{I}-\mathrm{J})\end{array}$ & $\begin{array}{c}\text { Standard } \\
\text { Error }\end{array}$ & Sig. \\
\hline \multirow{4}{*}{ Glucose } & $\begin{array}{c}\text { Positive Control } \\
\text { (K 3) } \\
\mathrm{N}=5\end{array}$ & $\begin{array}{l}\text { Extract } 250 \mathrm{mg} \\
\text { Extract } 500 \mathrm{mg} \\
\text { Extract } 1000 \mathrm{mg}\end{array}$ & $\begin{array}{l}301.80^{*} \\
403.60^{*} \\
399.00^{*}\end{array}$ & $\begin{array}{l}27.990 \\
27.990 \\
27.990\end{array}$ & $\begin{array}{l}0.000 \\
0.000 \\
0.000\end{array}$ \\
\hline & $\begin{array}{l}\text { Extract } 250 \mathrm{mg} \\
\quad(\mathrm{K} 4) \\
\mathrm{N}=5\end{array}$ & $\begin{array}{l}\text { Positive Control } \\
\text { Extract } 500 \mathrm{mg} \\
\text { Extract } 1000 \mathrm{mg}\end{array}$ & $\begin{array}{r}-301.80^{*} \\
101.80^{*} \\
97.20^{*}\end{array}$ & $\begin{array}{l}27.990 \\
27.990 \\
27.990\end{array}$ & $\begin{array}{l}0.000 \\
0.002 \\
0.003\end{array}$ \\
\hline & $\begin{array}{l}\text { Extract } 500 \mathrm{mg} \\
\qquad \begin{array}{c}(\mathrm{K} 5) \\
\mathrm{N}=5\end{array}\end{array}$ & $\begin{array}{l}\text { Positive Control } \\
\text { Extract } 250 \mathrm{mg} \\
\text { Extract } 1000 \mathrm{mg}\end{array}$ & $\begin{array}{r}-403.60 * \\
-101.80 * \\
-4.60\end{array}$ & $\begin{array}{l}27.990 \\
27.990 \\
27.990\end{array}$ & $\begin{array}{l}0.000 \\
0.002 \\
0.872\end{array}$ \\
\hline & $\begin{array}{l}\text { Extract } 1000 \mathrm{mg} \\
\qquad \begin{array}{c}(\mathrm{K} 6) \\
\mathrm{N}=5\end{array}\end{array}$ & $\begin{array}{l}\text { Positive Control } \\
\text { Extract } 250 \mathrm{mg} \\
\text { Extract } 500 \mathrm{mg}\end{array}$ & $\begin{array}{r}-399.00^{*} \\
-97.20 * \\
4.60\end{array}$ & $\begin{array}{l}27.990 \\
27.990 \\
27.990\end{array}$ & $\begin{array}{l}0.000 \\
0.003 \\
0.872\end{array}$ \\
\hline
\end{tabular}


Citrulline fucntions as a precursor to NO formation, where NO was directly involved in the regulation of insulin secretion by causing membrane depolarization and the enhancement of intracellular $\mathrm{Ca} 2+$ concentration. NO, which was inside the cell, wold cause retention of intracellular $\mathrm{K}+$ which caused membrane depolarization, then opened $\mathrm{Ca} 2+$ channel so that $\mathrm{Ca} 2+$ influx increased, insulin secretion occured.Furthermore it stimulated glycogenesis in the liver thereby reducing blood glucose levels. (Laffranchi 2002).

Administering watermelon skin extract dose of 250 $\mathrm{mg} / \mathrm{kg}$ bw/day was significantly different from the extract group $500 \mathrm{mg} / \mathrm{kg} \mathrm{bw} /$ day and group 1000 $\mathrm{mg} / \mathrm{kg} /$ day. This is likely due to the mechanism of increasing insulin secretion by NO. The more NO that was produced from the watermelon rind, the higher the insulin produced and ultimately would reduce serum glucose levels. In this case the work of $\mathrm{NO}$ in accordance with the work of oral anti-diabetic drugs in the sulfonylurea class is to increase insulin secretion (Suparman.2003). A dose of $500 \mathrm{mg}$ of watermelon rind water extract ddi not differ from a dose of $1000 \mathrm{mg}$, meaning that the administration of $500 \mathrm{mg}$ had the same effect as administering of $1000 \mathrm{mg}$. This was likely due to the role of NO which caused GLUT 4 translocation on the surface of cell membranes.

Intracellular GLUT 4 translocation stimulated by NO actually started from insulin binding to receptors in the extracellular part. This bond stimulated the formation of several phosphorylation reactions that were very important for insulin work. Auto-phosphorylation of the tyrosine group from the resetor protein stimulated by insulin would strengthen the work of the tyrosine kinase enzyme, which then phosphorylates some intracellular proteins including IRS-1. Phosphorylation of IRS-1, results in secondary signals that connect the insulin receptor to trans-membrane glucose transport. Furthermore, phosphoinositol-3 kinase activation was needed for stimulation of glucose transport by insulin and was needed to induce GLUT 4 translocation to the plasma membrane (Larsen et al, 2003). At a dose of $500 \mathrm{mg}$, NO had been maximal in increasing the sensitivity of insulin receptor through GLUT 4 translocation to the plasma membrane, which caused signal transduction. In this case, NO mechanism of action was similar to oral antidiabetic drugs grouped in thiazolidenedtiones (TZDs) or glitazones as insulin sensitizers. The mechanism was to increase glucose uptake in peripheral tissues and decrease liver glucose production (Dagogo et al 1997). To know exactly the mechanism of action of NO as a compound that could reduce blood glucose levels, further research could be carried out by examining HOMA B and HOMA $\mathrm{R}$ in experimental animals made with DM.

\section{CONCLUSION}

Watermelon water rind extracts of $250 \mathrm{mg} / \mathrm{kg} \mathrm{bw} /$ day, $500 \mathrm{mg} / \mathrm{kg}$ bw/day, and $1000 \mathrm{mg} / \mathrm{kg}$ bw/day could reduce serum glucose levels in male white rats injected with a single dose of streptozotosin $50 \mathrm{mg} / \mathrm{kg}$ given intraperitoneally with the optimal dose of watermelon rind water extract dose of $500 \mathrm{mg} / \mathrm{kg}$ bwi/day.

\section{REFERENCES}

Cattopadhyay RR, Bandyopadyay M (2005). Effect of Azadirachta indica leaf extract om serum lipid profile changes in normal and streptozotosin induced diabetic rats. African Journal of Biomedical Reseach 8, 101-104

Dods RF, 1996. Diabetes mellitus, In Clinical Chemistry: Theory, Analysis, Correlation, Eds, Kaplan L.A, Pesce A.J, 3rd Ed. USA, Mosby Inc, p 613-640

Jakus V (2000). The role of free radicals, oxidative stress and antioxidant systems in diabetic vascular disease. Bratisl Lek Listy 101, 541-551

Joeliantina A (2008). Pengaruh pemberian ekstrak biji jambalng (Eugena jambolana) terhadap kadar glukosa dan profil lemak serum tikus putih jantan (Rattus norvegicus) yang diinduksi streptozotosin. A thesis. Surabaya, Program Pasca Sarjana Universitas Airlangga

Laffranchi R, Gogvadze V, Richter C, Spinas GA (2002). Nitric oxide (Nitrogen Monoxide, No) stimulates insulin secretion by inducing calcium release from mitochondria

Larsen K (2003). Williams Textbook of Endocrinology. 10th Ed, p 45-49

Murray RK, Granner DK, Mayes PA, Rodwell VW (2003). Biokimia Harper. 25th Ed. Jakarta, EGC, p 203261

Payne C (2002). Complication of diabetes. Diabetes Lecture 2, Health Sciences, Department of Pediatry, $p$ 200

Rimando AM, Perkins-Veazie PM (2005). Determination of citrulline in watermelon rind. J Chromatogr A 1078, 196-200

Sacks DB (2001). Carbohydrates, In Tietz Fundamentals of Clinical Chemistry, Eds Burtis C.A, Ashwood E.R, 5th Ed, USA, W.B. Saunders Company, p 427-461

Subroto (2006). Ramual herbal untuk diabetes melitus. Penebar Swadaya, p 20-50

Suparman (2003). Buku ajar ilmu penyakit dalam. Jakarta, Gaya Baru, Jakarta, p 571

Szkudelski T (2001). The mechanism of alloxan and streptozotosin action in B cell of the rat pancreas: Minireview. Physiological Research 50, 536-546 